\title{
Interferon- $\gamma$ regulates growth and controls Fc $\gamma$ receptor expression and activation in human intestinal mast cells
}

\author{
Gernot Sellge ${ }^{1^{*}}$, Miriam Barkowsky², Sigrid Kramer ${ }^{3}$, Thomas Gebhardt ${ }^{4}$, Leif E Sander ${ }^{5}$, Axel Lorentz ${ }^{3}$ \\ and Stephan C Bischoff ${ }^{3}$
}

\begin{abstract}
Background: Development and function of tissue resident mast cells (MCs) is tightly controlled by various cytokines, most of which belong to the typical T helper (Th) 2-type cytokines such as IL-3 and IL-4. The effects of the Th1-type cytokine IFN- $\gamma$ on human MCs is less clear.

Results: Here, we analyzed the effects of IFN- $y$ on tissue-derived, mature human MCs. We found that INF- $y$ decreases proliferation, without affecting apoptosis in human intestinal MCs cultured in the presence of optimal concentrations of stem cell factor (SCF) or SCF and IL-4. However, in the absence of growth factors or at suboptimal concentrations of SCF, INF- $\gamma$ promotes survival through inhibition of MC apoptosis. Interestingly, we found that INF- $\gamma$ has no effect on FceRl expression and FceRl-mediated release of histamine and leukotriene $(L T) C_{4}$, while it has profound effects on FcyR expression and activation. We show that intestinal MCs express FcyRl, FcyRlla, and FcyRllc, whereas FcyRllb expression was found in only $40 \%$ of the isolates and FcyRIII was never detectable. INF- $\gamma$ strongly increases FcyRI and decreases FcyRlla expression. INF- $\gamma$-naïve MCs produce $\mathrm{LTC}_{4}$ but fail to degranulate upon crosslinking of surface-bound monomeric IgG. In contrast, INF- $\gamma$-treated MCs rapidly release granule-stored histamine in addition to de novo-synthesized LTC 4 .

Conclusion: In summary, we identify INF- $\gamma$ as an important regulator of tissue-resident human MCs. IFN- $\gamma$ displays a dual function by blocking extensive MC proliferation, while decreasing apoptosis in starving MCs and enhancing FcyRI expression and activation. These results emphasize the involvement of mucosal MCs in Th1-mediated disorders.
\end{abstract}

Keywords: Human, Mast cells, Intestine, Interferon- $\gamma$, Fcy receptors

\section{Background}

The inarguable key role of mast cells (MCs) in allergic disorders is well established [1]. Moreover, there is a growing evidence for the important functions of MCs in host defense against parasitic and bacterial pathogens [2], autoimmune diseases [3], and other chronic inflammatory processes such as atherosclerosis [4]. Immature $\mathrm{MC}$ progenitors migrate from the bone marrow via the peripheral blood into the tissue, where they undergo final maturation. Consequently, human MCs can be developed in vitro from bone marrow, cord blood, and peripheral blood cells in the presence of Stem cell factor

\footnotetext{
* Correspondence: gsellge@ukaachen.de

'Department of Internal Medicine III, University Hospital Aachen, RWTH

University, Aachen, Germany

Full list of author information is available at the end of the article
}

(SCF), the essential MC growth factor required for $\mathrm{MC}$ development and maintenance [1]. However, the phenotype of mature tissue-resident MCs is dictated by the local microenvironment. Therefore, MCs of different tissues exhibit remarkable differences in biochemical and functional properties [1]. The functional properties of MCs are significantly altered under pathological conditions and the cytokine milieu is considered a key factor in this regulation. Th2 type cytokines such IL-3, IL-4, IL-5, and IL-9 have been shown to enhance human MC growth, to increase degranulation and to enhance the production of eicosanoids and many cytokines upon FceRI-crosslinking [1,5-7]. These findings mainly explain elevated $\mathrm{MC}$ numbers and enhanced activity in Th2 type disorders $[1,8]$.

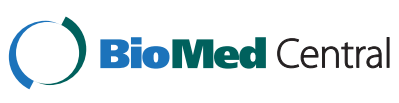

(c) 2014 Sellge et al.; licensee BioMed Central Ltd. This is an Open Access article distributed under the terms of the Creative Commons Attribution License (http://creativecommons.org/licenses/by/4.0), which permits unrestricted use, distribution, and reproduction in any medium, provided the original work is properly credited. The Creative Commons Public Domain Dedication waiver (http://creativecommons.org/publicdomain/zero/1.0/) applies to the data made available in this article, unless otherwise stated. 
INF- $\gamma$ is the hallmark cytokine of Th1-mediated disorders such as auto-immune diseases and Crohn's disease. It is mainly produced by NK and T cells and acts on many cells including dendritic cells, macrophages, and MCs [9]. For a long time INF- $\gamma$ has been mainly considered as an inhibitory factor for MCs. Reports on rodent MCs have shown that INF- $\gamma$ decreases MC development $[10,11]$ and FceRI-dependent activation $[12,13]$. However, more recent studies using human peripheral blood-derived MCs indicate that INF- $\gamma$ does not affect IgE-dependent degranulation and induces the expression of the FcyRI rendering MCs responsive to IgG-crosslinking [14]. There is conflicting data concerning the role of IFN- $\gamma$ as a MC growth factor, since IFN- $\gamma$ has been reported to either inhibit [15,16], promote [17], or to have no effect [15] on MC survival. These contradictory results might be explained by varying maturation states of the in vitro derived MCs. Kulka and Metcalfe showed that MC growth is strongly inhibited if INF- $\gamma$ is added to early MC progenitors by both inhibiting proliferation and inducing apoptosis whereas the growth of differentiated peripheral blood-derived MCs was only slightly affected by INF- $\gamma[15]$.

Similar findings have been described for other cytokines which is best exemplified by the effect of IL-4 on MCs. It is well established that IL-4 decreases the growth of early $\mathrm{MC}$ progenitors [7,15,18]. This effect seems to be turned to the opposite in more differentiated MCs. For late stage in vitro differentiated MCs it has been reported that IL-4 slightly decreases [7], slightly increases [16], or strongly increases [15] MC growth. Importantly, besides stem cell factor (SCF), IL-4 is the most potent cytokine inducing $\mathrm{MC}$ proliferation and enhancing IgE-dependent mediator release in tissuederived human MCs [7,19].

These findings reveal the complex biology of human MCs, which can only be understood in detail if the results of studies on human MCs derived from different sources are compiled. Here we studied the regulatory effects of IFN- $\gamma$ on purified human mucosal MCs. We demonstrate a dual role of INF- $\gamma$ in the regulation of $\mathrm{MC}$ growth. Addition of IFN- $\gamma$ inhibits the proliferation of MCs cultured under optimal growth conditions on the one hand. On the other hand, in the absence of the essential MC growth factor SCF, IFN- $\gamma$ partly rescues MC survival by inhibiting apoptosis. Moreover, we demonstrate profound effects of IFN- $\gamma$ on the functional properties of MCs. While it does not alter the expression or responsiveness of the high affinity FceRI, IFN- $\gamma$ upregulates expression levels of FcyRI on MCs. Crosslinking of surface-bound monomeric IgG on IFN- $\gamma$ treated MCs induced degranulation and release of histamine as well as production of leukotriene $(\mathrm{LT}) \mathrm{C}_{4}$, whereas IFN- $\gamma$ naïve $\mathrm{MCs}$ failed to degranulate and released only low levels of (LT) $\mathrm{C}_{4}$. Thus, IFN- $\gamma$ represents an important regulator of mature human MCs, which may have important implications during Th1 mediated diseases.

\section{Results}

IFN- $\gamma$ has a dual role for MC growth by differentially regulating $M C$ proliferation and apoptosis

IFNGRI mRNA is expressed in human intestinal MCs and the expression level is not changed by IL-4 or by FceRI-crosslinking (Figure 1A). We tested whether IFN$\gamma$ has an impact on $\mathrm{MC}$ growth. To this end, we cultured MCs in the presence of optimal concentrations of SCF or SCF and IL-4 and various concentrations of IFN- $\gamma$. IFN- $\gamma$ decreased the MC recovery after 14 days in a dose-dependent manner with a maximal effect at concentrations $\geq 30 \mathrm{ng} / \mathrm{ml}$ (Figure $1 \mathrm{~B}$ ). To analyze the time kinetic of this effect we determined $\mathrm{MC}$ numbers at day 3,7 , and 14. The growth inhibitory effect of IFN- $\gamma$, which was significant at day 14, could not be detected at day 3 and was not significant at day 7, although there was already a strong tendency towards reduced $\mathrm{MC}$ numbers in cultures with IFN- $\gamma$ (Figure 1C/D). To better understand the role of IFN- $\gamma$ during $\mathrm{MC}$ growth, we lowered the concentrations of the dominant growth factor SCF. Intestinal MCs cultured in medium alone or in the presence of suboptimal concentrations of SCF (5 ng/ml), died completely or were strongly reduced in numbers, respectively. Surprisingly, IFN- $\gamma$ partly inhibited the decline of MC numbers under these culture conditions, although the effect did not reach statistical significance (Figure 1E/F).

To further investigate the underlying mechanisms of the pro-survival effect of IFN- $\gamma$ we studied ${ }^{3} \mathrm{H}$-Tymidin incorporation, as a measure of $\mathrm{MC}$ proliferation as well as Caspase 3/7 activity to determine apoptosis. MCs cultured in medium alone or in the presence of $5 \mathrm{ng} / \mathrm{ml}$ SCF generally showed very low rates of ${ }^{3} \mathrm{H}$-Tymidin incorporation, which was unchanged by IFN- $\gamma$ treatment. Confirming previous results, we found high rates of ${ }^{3} \mathrm{H}$ Tymidin incorporation in MCs cultured with $50 \mathrm{ng} / \mathrm{ml}$ SCF, which was even more pronounced in MCs cultured in the presence of $50 \mathrm{ng} / \mathrm{ml} \mathrm{SCF}$ and $2 \mathrm{ng} / \mathrm{ml} \mathrm{IL-4}$ $[7,20]$. MC proliferation under these conditions was significantly inhibited if IFN- $\gamma$ was added to the culture medium. This effect was observed after 3 days (Figure 2A) and 7 days of culture (not shown), although the decrease in cell numbers was significant only after 14 days (Figure 1C/D). This might be explained by the overall slow proliferating phenotype of MCs in vitro, which makes changes in the proliferation levels only detectable by cell counting at later time points [7].

Caspase 3/7 activity was low in MCs cultured in the presence of $50 \mathrm{ng} / \mathrm{ml} \mathrm{SCF}$ with or without IL-4. IFN- $\gamma$ did not influence caspase $3 / 7$ activity under these conditions. In contrast, IFN- $\gamma$ significantly inhibited caspase 


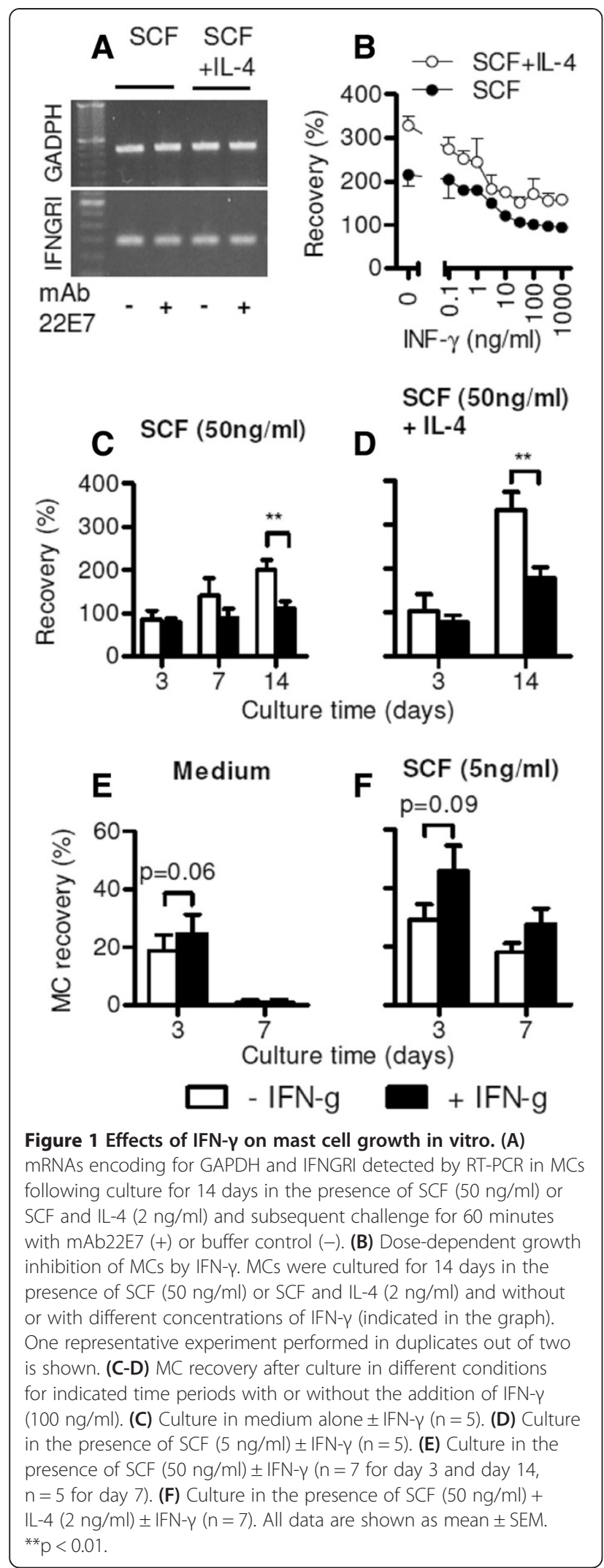

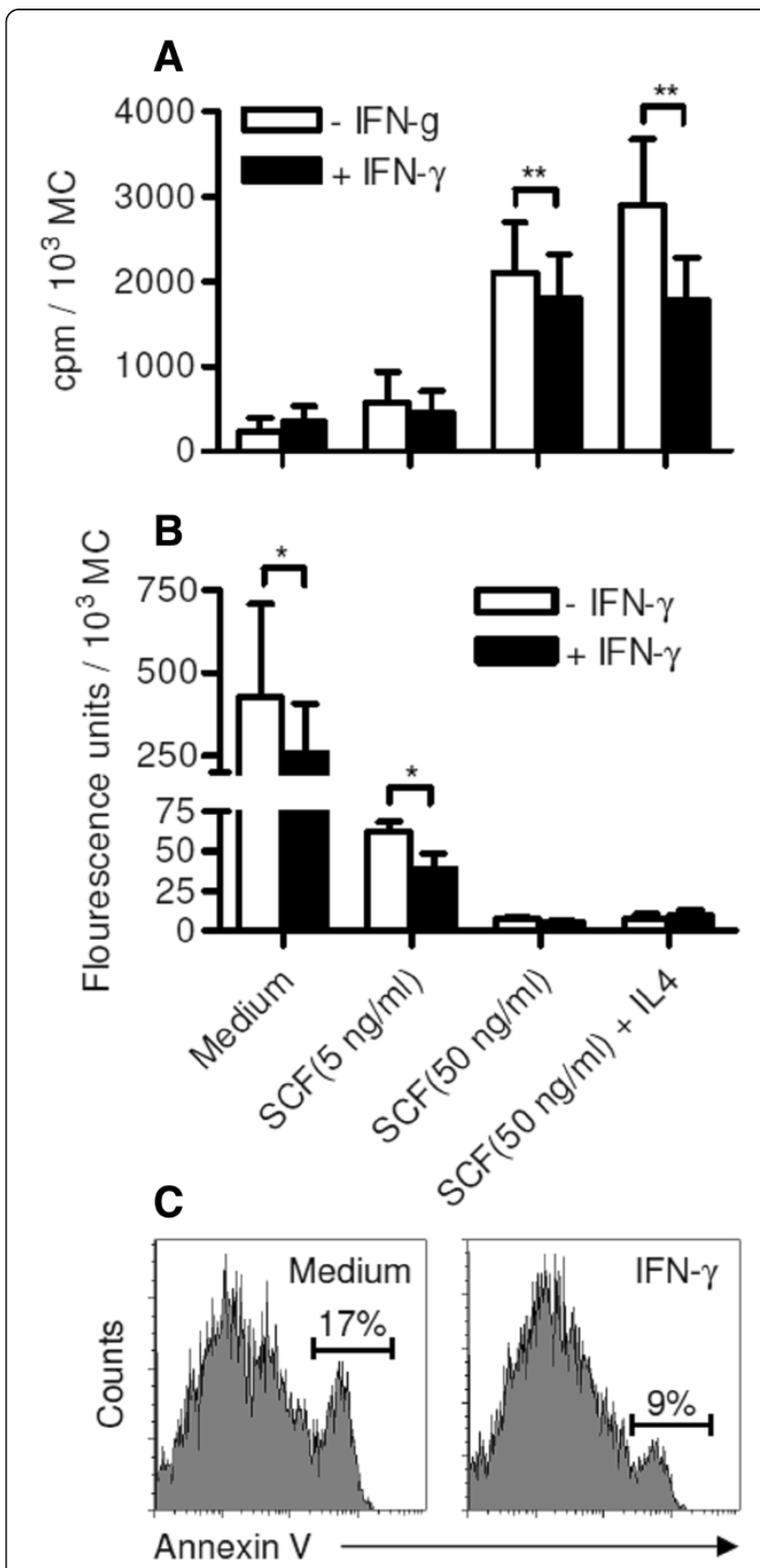

Figure 2 Effects of IFN- $\gamma$ on proliferation and apoptosis of intestinal MCs. (A/B) MCs were cultured for 3 days in the conditions described in Figure 1C-F. (A) $\left[{ }^{3} \mathrm{H}\right]$ thymidine (0.5 Ci/well) was added for the final $12 \mathrm{~h}$ of culture to assess MC proliferation. Incorporation of $\left[^{3} \mathrm{H}\right]$ thymidine into the cells was measured and is depicted as $\mathrm{cpm} / 10^{3} \mathrm{MCs}$. Mean \pm SEM of 5 (medium and SCF $5 \mathrm{ng} / \mathrm{ml}$ ) or 7 independent experiments (SCF $50 \mathrm{ng} / \mathrm{ml}$ and SCF + IL-4) performed in duplicates. (B) Caspase 3/7 activity was determined and is shown as fluorescence units $/ 10^{3}$ MCs. Mean \pm SEM of 5 independent experiments performed in duplicates. (C) Surface binding of annexin $V$ measured by FAVS following culture of MC for 3 days with IFN- $\gamma(100 \mathrm{ng} / \mathrm{ml})$ or medium alone. One representative experiment out of two is shown. ${ }^{*} p<0.05 ;{ }^{* *} p<0.01$. 
3/7 activity in MCs cultured in the presence of $5 \mathrm{ng} / \mathrm{ml}$ or without SCF (Figure 2B). The anti-apoptotic effect of IFN- $\gamma$ in MCs was further confirmed by FACS analysis of annexin $\mathrm{V}$ binding, a marker for early apoptosis (Figure 2C).

\section{IFN- $\gamma$ does not change histamine content, FceRI} expression, and FcERI-dependent mediator release We reported previously that cytokines affecting $\mathrm{MC}$ growth such as IL-3, IL-4, and TGF- $\beta$ also regulate the functional response of intestinal MCs to FceRI-crosslinking [5,21,22]. Here we show that IFN- $\gamma$ has no effect on the histamine content in MCs (Figure 3A), and the release of histamine and $\mathrm{LTC}_{4}$ upon FceRI-crosslinking (Figure 3B/D). Our results confirms that IL-4 upregulates FceRI-dependent histamine and $\mathrm{LTC}_{4}$ liberation [7] and this effect is not counter-regulated by IFN- $\gamma$ (Figure 3B/D). In line with the functional data, we found that IFN- $\gamma$ did not change the expression level of the FceRI (Figure 4A). FcoRI was not detectable in intestinal MCs cultured with SCF alone or SCF + IFN- $\gamma$ (Figure 4B). IFN- $\gamma$ strongly induced the expression of the $\mathrm{MCH}$ class II protein HLA-DR in human intestinal MCs (Figure 4C) confirming studies on rodent MCs, the human MC line HMC-1 and human progenitor cell-derived MCs [23-26].

IFN- $\gamma$ upregulates FcyRI expression and the functional response to IgG-crosslinking

We sought to investigate $\mathrm{Fc} \gamma$ receptor expression and function and the regulatory impact of IFN- $\gamma$ in human intestinal MCs. We found that human intestinal MCs express mRNA for Fc $\gamma$ RI, Fc $\gamma$ RIIa, and Fc $\gamma$ RIIc at steady state (Figure 5A). Very low amounts of FcyRIIb1 and higher levels of FcyRIIb2 expression was only detected in 4 out of $10 \mathrm{MC}$ preparations derived from different donors (Figure 5A and data not shown) and FcyRIII expression was not detectable in any of the samples (Figure 5A). FACS analysis confirmed the mRNA results as we detected FcyRI and FcyRII (subtypes could not be differentiated by the mAb), but no FcyRIII expression on the cell surface. IFN- $\gamma$ increased the expression of the Fc $\gamma$ RI on mRNA and protein level (Figure 5A/B). Fc $\gamma$ RII expression of intestinal MCs was downregulated by IFN- $\gamma$ (Figure 5B). The mRNA analysis suggests that this regulation was dependent on the decreased expression of FcyRIIa, whereas FcyRIIc expression was not affected (Figure 5A). IL-4, IL-10, G-CSF, or GM-CSF had no influence on the expression level of FcyRs in human intestinal MCs (data not shown).

Next, we investigated the binding of IgG subtypes on intestinal MCs by flow cytometry. We found that MCs bound myeloma IgG1 and IgG3 which was significantly increased by IFN- $\gamma$. Marginal binding of IgG4 was found

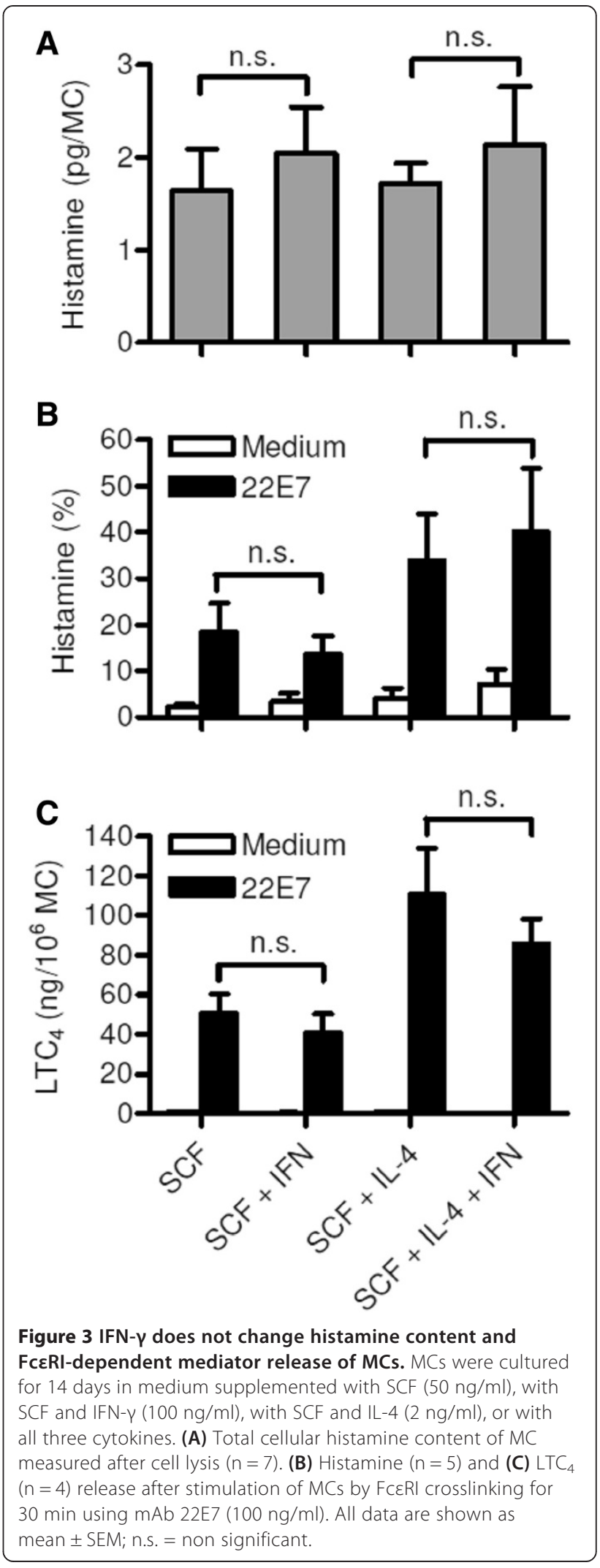




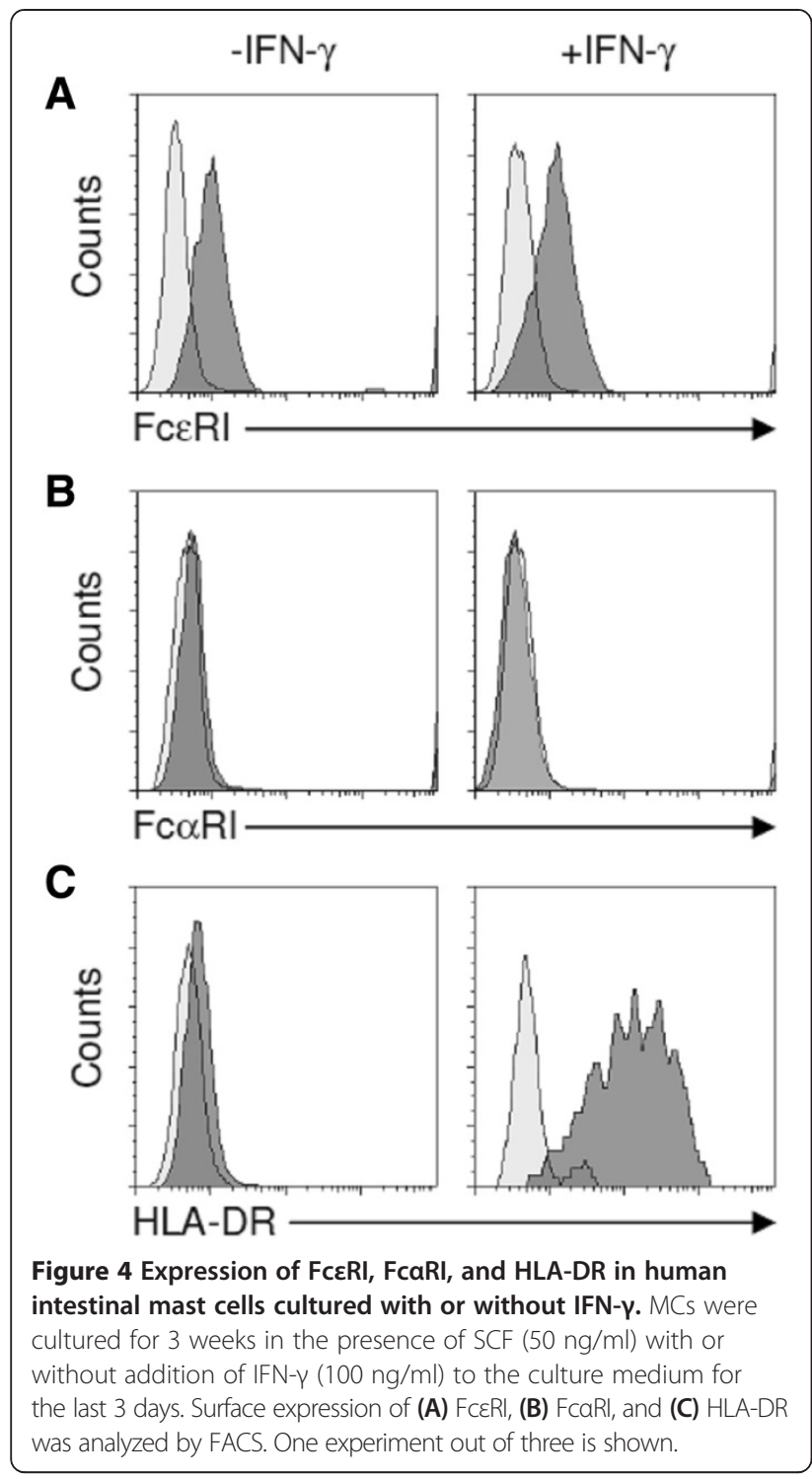

on IFN- $\gamma$ treated MCs, whereas IgG2 binding was absent in all tested conditions (Figure 6).

To characterize the functional response of human intestinal MCs to IgG-crosslinking we sensitized MCs with plasma IgG for $24 \mathrm{~h}$ and subsequently challenged the cells with an anti-human IgG mAb. Primary human MCs cultured in the absence of IFN- $\gamma$ failed to release stored histamine upon Fc $\gamma \mathrm{R}$ activation. Interestingly, Fc $\gamma \mathrm{R}$ stimulation of IFN- $\gamma$ treated MCs induced degranulation and rapid release of histamine contents (Figure 7A). IFN- $\gamma$ treated and untreated MCs produced similar amounts of $\mathrm{LTC}_{4}$ upon IgG-crosslinking (Figure 7B). In summary, these results indicate that IFN- $\gamma$ induces upregulation of FcyRI expression and renders intestinal MCs responsive to IgG-induced degranulation, whereas IgGdependent production of de-novo synthesized eiconsanoids is independent of IFN- $\gamma$.
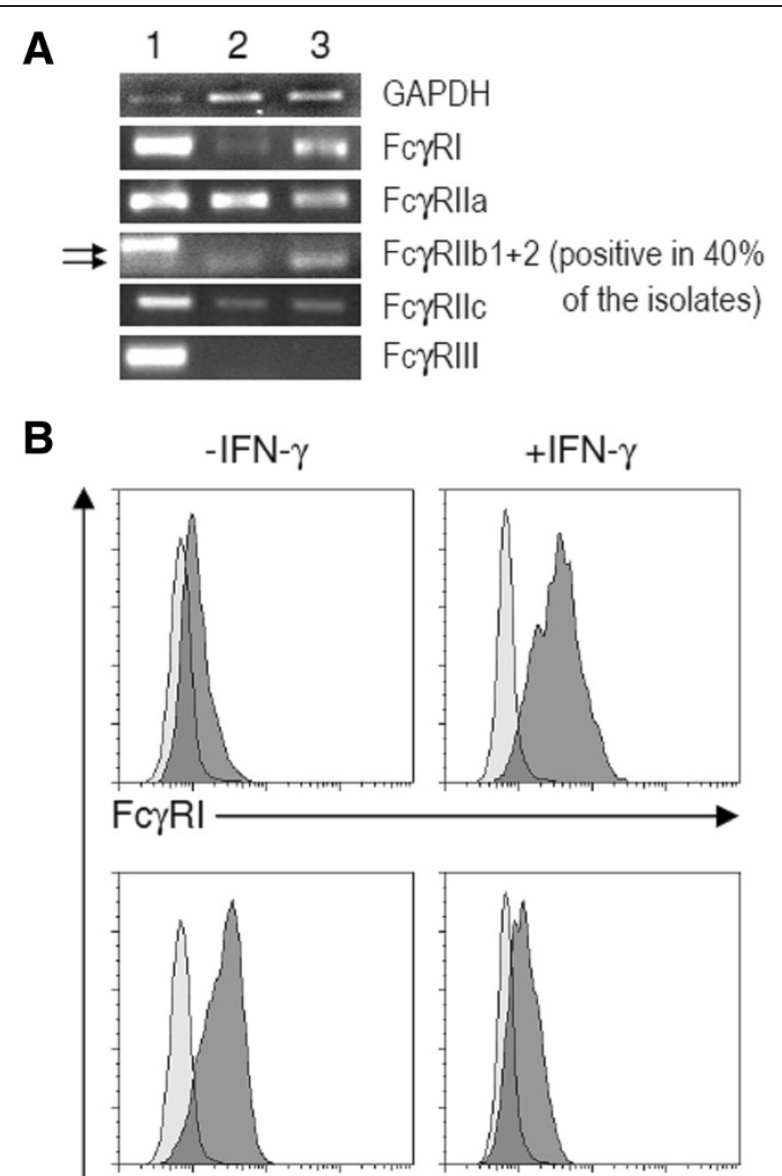

FcyRII
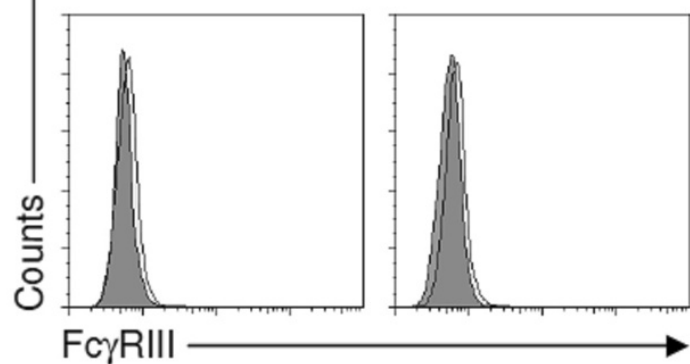

Fc $\gamma$ RIII

Figure 5 Expression of Fcy receptors in human intestinal mast cells. (A) PCR detecting mRNAs encoding for GAPDH, FcyRl, FcyRlla, FcyRllb, FcyRllc, and FcyRIll. For FcyRllb the two isoforms FcyRllb1 (343 bp) and FcyRllb2 (289 bp) were detected. Lane 1: PBMCs (positive control). Lane 2: intestinal MCs cultured in the presence of SCF (50 ng/ml). Lane 3: intestinal MCs from the same donors cultured in the presence of SCF and IFN- $\gamma(100 \mathrm{ng} / \mathrm{ml})$ for the last 3 days. One experiment out of 10 is shown. FcyRllb expression was found in MCs derived from 4 out of 10 donors (data not shown). (B) Surface expression of FcyRl (CD64), FcyRII (CD32), and FcyRIII (CD16) following culture of MC in the presence of SCF with or without the addition of IFN- $\gamma(100 \mathrm{ng} / \mathrm{ml})$ for the last 3 days. One experiment out of three is shown.

\section{Discussion}

In the present study, we identify IFN- $\gamma$ as an important regulator of human intestinal MCs. IFN- $\gamma$ decreases the 


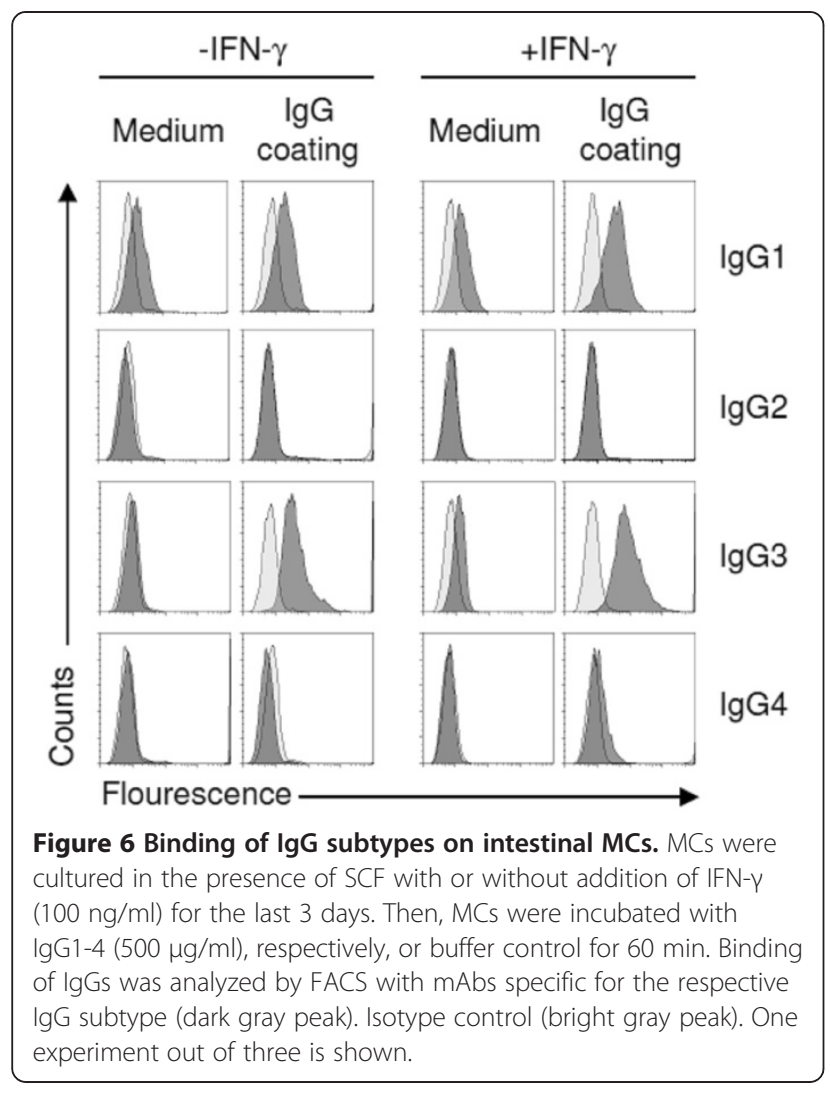

proliferation of human intestinal MCs cultured in the presence of high doses of SCF and, even more importantly, in the presence of SCF + IL-4. We further found that IFN- $\gamma$ does not have an impact on the apoptosis rates of human intestinal MCs cultured in the presence of $50 \mathrm{ng} / \mathrm{ml}$ of SCF with or without IL-4. In contrast, we found that IFN- $\gamma$ reduces apoptosis in MCs cultured in the presence of suboptimal concentration of SCF or in medium alone. These findings explain some of the discrepancies observed in previous studies. IFN- $\gamma$ inhibits the development of MCs in vitro by inhibiting proliferation and inducing apoptosis of $\mathrm{MC}$ progenitors $[11,15,27]$. However, the effects of IFN- $\gamma$ on differentiated MCs seemed to be contradictory in different studies. IFN- $\gamma$ has been shown to act on human cord-bloodderived MCs in one study by decreasing survival and proliferation [16] and in another study by promoting survival and inhibiting apoptosis [17]. The main difference in the two study protocols is the presence of $100 \mathrm{ng} / \mathrm{ml} \mathrm{SCF}$ in the MC cultures in the first report in contrast to the complete lack of growth factors during IFN- $\gamma$ exposure in the latter publication. Therefore, our data confirm the results of both studies and reveal the divergent effects of IFN- $\gamma$ on MC survival depending on the cross-talk with other growth factors. A recent study suggested that IFN- $\gamma$ does not affect the growth of human peripheral blood-derived MCs. In this study MCs
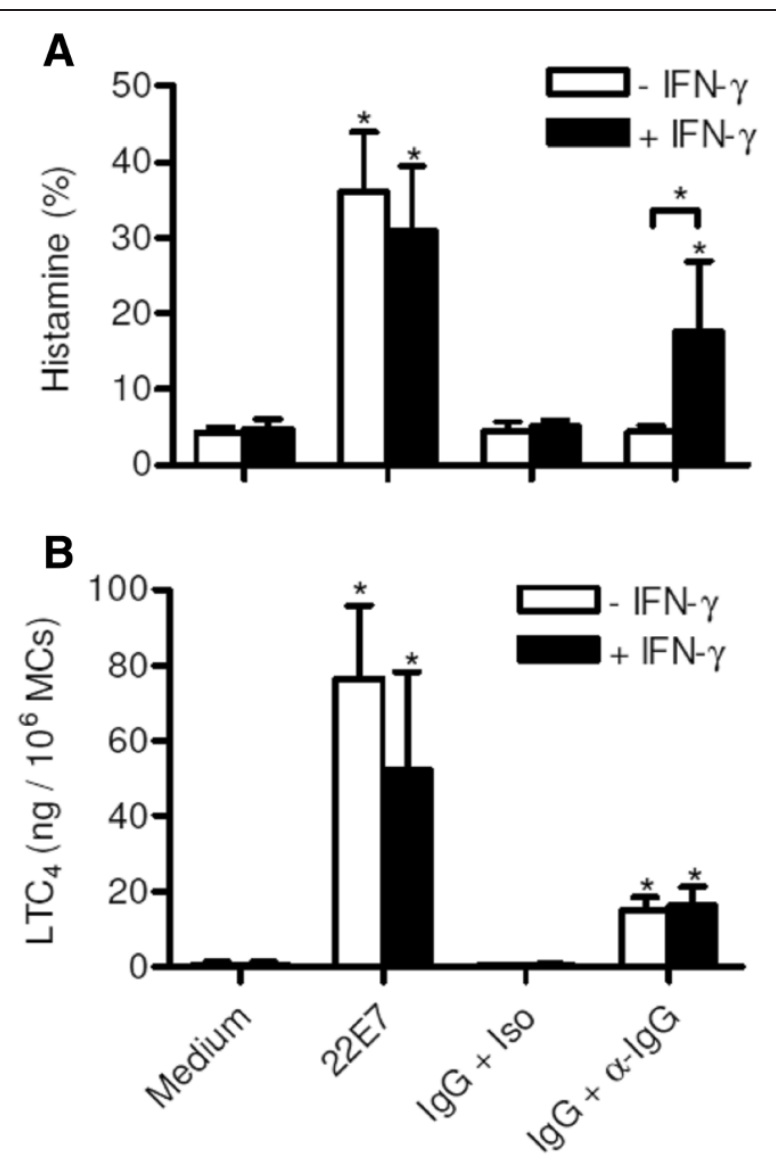

Figure 7 Histamine and $\mathrm{LTC}_{4}$ release from intestinal MCs after IgG-crosslinking. MCs were cultured with SCF and with or without IFN- $\gamma(100 \mathrm{ng} / \mathrm{ml})$ for 2 days. The last $24 \mathrm{~h}$ plasma lgG $(10 \mu \mathrm{g} / \mathrm{ml})$ was added to the culture medium if indicated. Then, MCs were washed and challenged with an anti-lgG mAb or and isotype control $\mathrm{mAb}$ for $60 \mathrm{~min}$. FceRl-crosslinking induced by mAb $22 \mathrm{E} 7$ served as positive control and non-treated MCs as negative control. (A) Histamine $(n=6)$ and $(\mathbf{B}) \operatorname{LTC}_{4}(n=4)$ were measured in the supernatants. Means \pm SEM are shown. ${ }^{*} \mathrm{p}<0.05$ (in comparison to medium control if not indicated otherwise).

were differentiated for 8 weeks in the presence of SCF and then further cultured with SCF and SCF + IFN- $\gamma$ for additional 7 days. Proliferation was tested by CSFEdilution within the last 7 days of the culture [15]. We found that intestinal MCs cultured in the presence of SCF only proliferate slowly. Consequently, the effect of IFN- $\gamma$ on proliferation was readily detectable by measuring $\left[{ }^{3} \mathrm{H}\right]$ thymidine incorporation, whereas significant differences in $\mathrm{MC}$ numbers were found only after 14 days of culture. Also in the study performed by Kulka and Metcalfe the differentiated MCs exhibited a low proliferation rate and in the presence of SCF only $28.5 \%$ of the cells divided within the 7 day of the investigation period. In the presence of SCF + IFN- $\gamma$ the division rate dropped to $19.3 \%$ [15]. Inhibition of proliferation of around 30\% correlates very well with the findings in our study. 
The in vivo effect of IFN- $\gamma$ on MCs is supposedly influenced by the microenvironment such as the local concentrations of other growth factors such as SCF or IL-4. These factors vary in physiological and different pathophysiological conditions. One might expect that IFN- $\gamma$ counter-regulate massive MC proliferation in Th2-type inflammatory diseases or dysregulated c-kit (SCF receptor) activation as it has been found in mastocytosis. Indeed, IFN- $\gamma$ treatment has been shown to improve the clinical symptoms of a mastocytosis patient [28]. On the other hand, increased IFN- $\gamma$ levels such as found in autoimmune diseases may stabilize or even elevate $\mathrm{MC}$ numbers in a less proliferation permissive environment. This may explain the high MC numbers frequently found in typical Th1 disorders such as rheumatoid arthritis [29] or psoriasis [30].

Recent studies employing mouse models have emphasized the role of $\mathrm{Fc} \gamma \mathrm{R}$-dependent activation of MCs in the development of immune-complex associated autoimmune diseases [3,31]. However, mouse MCs express only the low-affinity IgG receptors FcyRII and FcyRIII, but not the high-affinity FcyRI. We show here that human intestinal MCs cultured in the presence of SCF alone express low levels of FcyRI. IFN- $\gamma$ treatment strongly increased its expression. Our findings are in agreement with recent immuno-histological studies demonstrating that in a small subset of intestinal MCs FcyRI is expressed during homeostasis, but that the frequency of Fc $\gamma \mathrm{RI}^{+} \mathrm{MCs}$ is strongly increased in patients with Crohn's disease, a disease which is associated with increased IFN- $\gamma$ levels [32]. The FcyRI ${ }^{+}$expression profile in intestinal MCs is very similar to what has been reported for MCs derived from peripheral and cord blood as well as skin and synovial MCs, which express no or very low levels of $\mathrm{Fc}_{\mathrm{C}} \mathrm{RI}^{+}$after culture with SCF [14,33-35]. However, in peripheral blooddervied MCs Fc $\gamma$ RI expression can be induced by IFN- $\gamma$ [14], and immuno-histological studies showed that skin MCs are negative for $\mathrm{Fc} \gamma \mathrm{RI}$ expression during homeostasis, while FcyRI expression can be detected in MCs of tissue samples derived from patients with psoriasis [36]. After sensitization with IgG, we detected the binding of IgG1 and IgG3 on the surface of MCs, which was increased after IFN- $\gamma$ exposure. Monomeric IgG only bind to the high affinity FcyRI with the highest affinities for IgG1 and IgG3, whereas low affinity FcyRII and III preferentially bind IgG complexes [37]. Enhanced binding of IgG1 and IgG3 to MCs cultured in the presence of IFN- $\gamma$ is, therefore, very likely caused by the increased expression of FcyRI. We found that IgG-crosslinking triggers histamine release only in IFN- $\gamma$-treated MCs, but not in MCs cultured without IFN- $\gamma$. This confirms recent studies showing that peripheral blood-derived MCs cultured in the presence of IFN- $\gamma$ release histamine and de-novo produced eicosanoids such as $\mathrm{LTC}_{4}$ and $\mathrm{PGD}_{2}$ and several cytokines such as IL-3, IL-5,
IL-6, IL IL-13, TNF, and GM-CSF after IgG-crosslinking $[14,38]$. In contrast to peripheral blood-derived MCs, intestinal MCs released $\mathrm{LTC}_{4}$ upon IgG-crosslinking without IFN- $\gamma$ pre-culture. The amount of $\mathrm{LTC}_{4}$ release was not increased in IFN- $\gamma$-treated MCs. This suggests that $\mathrm{LTC}_{4}$ production can be induced by low level Fc $\gamma$ RI aggregation, whereas the threshold for the induction of $\mathrm{MC}$ degranulation is higher and requires more pronounced Fc $\gamma$ RI-dependent signals.

Furthermore, we found that intestinal MCs express mRNA for FcyRIIa and FcyRIIc, but not FcyRIII. FcyRIIb was expressed in $40 \%$ of the MC isolates. The expression of Fc $\gamma$ RIIa mRNA was downregulated by IFN- $\gamma$, which correlated with increased detection of Fc $\gamma$ RII surface expression using a Pan-FcyRII mAb. The expression profile of lowaffinity FcyRs differs in MCs derived from different sources. Peripheral-blood derived MCs express FcyRIIa, FcyRIIb, and FcyRIII, but no FcyRIIc [39]. Cord-blood derived MCs encode mRNA for FcyRIIa, FcyRIIb, and FcyRIIc, but no FcyRIII; however, only FcyRIIb protein expression could be detected [34]. In contrast, skin MCs express only FcyRIIa and no FcyRIIb, FcyRIIc, and FcyRIII [33]. Synovial MCs express FcyRIIa, FcyRIIb, and FcyRIIc, and no FcyRIII, however; they dowregulate FcyRIIb expression upon culture [35]. The low-affinity IgG receptors FcyRIIa, Fc $\gamma$ RIIc, FcyRIII are activating receptors that signal as Fc $\gamma$ RI via immunoreceptor tyrosin-based activation motifs (ITAM) and are aggregated by immune-complexes. They are expressed on many innate immune cells and exert various effector pathways, such as phagocytosis, antibody-dependent cellular cytotoxicity, and the release of chemotactic and pro-inflammatory mediators [40]. Human skin and synovial MCs, however not peripheral-blood derived MCs, have been shown to degranulate and secrete eicosanoids and cytokines upon aggregation of FcyRIIa [33,35,39]. However, recently Fc $\gamma$ RIIa has been suggested to decrease IgE-mediated activation of basophils by a yet undefined mechanism [41]. FcyRIIb is an inhibitory Fc receptor and transmits its signals via immunoreceptor tyrosin-based inhibitory motifs (ITIM) [42]. Fc $\gamma$ RIIb inhibits IgE-induced activation of human basophils and cord blood-derived MC [34,43]. Polymorphisms in the promoter and transmembrane region causes decreased expression of FcyRIIb and are linked to lupus erythematosus. We found inconsistent expression of FcyRIIb in human intestinal MCs which may be explained by genetic variability of the donors [44]. The cellular response after aggregation of low-affinity IgG receptors on intestinal MCs has not been addressed in the current study and requires further investigation.

\section{Conclusion}

In summary, we define IFN- $\gamma$ as an important regulator of human intestinal MCs. IFN- $\gamma$ provides inhibitory 
signals such as blocking extensive MC proliferation and activating signals such as decreasing apoptosis in starving MCs, inducing the expression of Fc $\gamma \mathrm{RI}$ and $\mathrm{MHC}$ class II molecules, and rendering MCs more responsive to IgG-crosslinking. This differential regulation of MCs might be of particular importance for $\mathrm{MC}$ function during Th1-type mediated diseases [3,31].

\section{Methods}

Isolation, purification, and culture of human intestinal MCs

MCs were isolated from surgical tissue specimens (macroscopically normal tissue) derived from individuals who underwent bowel resection because of cancer. Written informed consent was obtained from all patients at least $24 \mathrm{~h}$ before surgery. The study was approved by the local ethical committee of the Medical School of Hannover, Germany, where the study was performed. The methods of mechanical and enzymatic tissue dispersion yielding single cell preparations have been described [45]. After overnight culture of the cell suspension in culture medium (RPMI 1640 supplemented with 10\% heat-inactivated fetal calf serum, $25 \mathrm{mM}$ HEPES, $2 \mathrm{mM}$ glutamine, $100 \mu \mathrm{g} / \mathrm{ml}$ streptomycin, $100 \mu \mathrm{g} / \mathrm{ml}$ gentamycin, 100 $\mathrm{U} / \mathrm{ml}$ penicillin, and $0.5 \mu \mathrm{g} / \mathrm{ml}$ amphotericin; all from Invitrogen, Karlsruhe, Germany) c-kit expressing MCs were enriched by positive selection using magnetic cell separation $\left(\right.$ MACS $^{\text {TM }}$ system, Miltenyi Biotech, BergischGladbach, Germany) and the anti-c-kit mAb YB5.B8 (5 ng/ml, PharMingen, Hamburg, Germany) as described [45]. The fraction containing the $c$-kit-positive cells (MC purity $50-90 \%)$ was cultured at a density of $1-2 \times 10^{5}$ $\mathrm{MC} / \mathrm{ml}$ in the presence of SCF $(50 \mathrm{ng} / \mathrm{ml}$, Amgen, Thousand Oaks, CA) for two weeks to obtain $>98 \%$ pure MCs. MCs were harvested, washed, and further cultured for 3-14 days in 96-well plates $\left(2 \times 10^{4} /\right.$ well $)$ without cytokines or in the presence of SCF, IL-4 (Novartis, Vienna, Austria) and/or IFN- $\gamma$ (Imukin, Boeringer Ingelheim Pharma GmbH \& Co., Ingelheim, Germany) at indicated concentrations. Once a week half of the culture medium was exchanged and cytokines were supplemented again.

\section{Detection of apoptosis and proliferation}

Apoptotic MCs were visualized by FACS using APCconjugated annexin V (Becton Dickinson) Caspase 3/7 activity was measured with the Apo-ONE $E^{\mathrm{mm}}$ Homogeneous Caspase 3/7 Assay (Promega, Madison, WI). For the analysis of cell proliferation MCs were cultured in 96-well plates $\left(2 \times 10^{4}\right.$ per condition) in the presence of indicted cytokines for 3 or 7 days. The cultures were pulsed with $1 \mu \mathrm{Ci}$ of $\left[{ }^{3} \mathrm{H}\right]$ thymidine (Amersham International, Amersham, UK) per well for the final $12 \mathrm{~h}$. The cells were harvested on unifilter plates by using an automatic cell harvester (FiltermateTM196). [ $\left.{ }^{3} \mathrm{H}\right]$ thymidine corporation was measured as counts per min on a Beckman Topcount.

\section{RNA preparation and RT-PCR}

Total RNA was prepared from 5-10 $510^{4} \mathrm{MCs}$ and RT-PCR was performed as described [22]. The following primers were used for RT-PCR: glyceraldehyde 3phosphate dehydrogenase (GAPDH; 5'-CAT CAC CAT CTT CCA GGA GC-3'; 5'-GAG GCA GGG ATG ATG TTC TG-3); IFNGRI (5'-CCA TCT CGG CAT ACA GCA AA-3'; 5'-CTC AGT GCC TAC ACC AAC TA3'); FcyRI (5'-CTT CTA CAT GGG CAG CAA GA-3'; 5'-GTT CTC TGG GTG ACA ATA CG-3'); Fc (5'-CAG CAT GGG CAG CTC TTC-3'; 5'-CAC ATG GCA TAA CGT TAC-3'); Fc $\gamma$ RIIb1/2 (5'-ATT GTT GCT GCT GTA GTG GCC-3'; 5'-GAA ACC TTC TCT TTT GGA ACT-3'); FcyRIIc (5'-TCT AGA TGA CCA CAT GGC ATA ACG-3'; 5'-CCT GGA CGT CAA ATG ATT GCC ATC-3'); FcyRIII (5'-CTT CTG GGA TAA GTG GAC TC -3; 5'-CTT CAT GGT TAG TGG TTC GTC-3).

\section{Flow cytometry}

FACS staining was performed as described recently [7]. MCs were labeled with primary antibodies anti-CD16-PE (Becton Dickinson, San Jose, CA), anti-CD32-PE, antiCD64-PE, anti-CD89 (Caltag Laboratories, Hamburg, Germany), FceRI $\alpha$-chain (mAb 22E7, Hoffmann-La Roche, kindly provided by R. Chizzonite), anti-HLA-DR, (DAKO A/S, Glostrup, Denmark) or appropriate isotype controls. Cells were washed and if purified primary $\mathrm{Ab}$ were used incubated with FITC-conjugated goat antimouse IgG1 (Southern Biotechnology, Birminghman, AL). FACS analysis was performed using the FACSCalibur ${ }^{\text {tw }}$ system (Becton Dickinson). Analysis were performed using the FlowJo software (Treestar, Inc. Ashland, OR).

\section{Analysis of IgG binding to MCs}

MCs were incubated for $60 \mathrm{~min}$ at $37^{\circ} \mathrm{C}$ with purified human myeloma IgG1, IgG2, IgG3, or IgG4 $(500 \mu \mathrm{g} / \mathrm{ml}$ in Hepes/BSA buffer; myeloma IgG purchased from Calbiochem, SanDiego, CA) or were left untreated. After washing anti-human IgG1 (cloneJDC-1), antihuman IgG2 (cloneG18-21), anti-human IgG3 (cloneG18-3), or anti-human IgG4 (cloneJDC-14) (all from Becton Dickinson) were applied for $30 \mathrm{~min}$ at $4^{\circ} \mathrm{C}$. Samples were washed and incubated with an FITC-conjugated goat anti-mouse IgG1 mAb (Southern Biotechnology). Binding of IgG subtypes were verified by FACS.

\section{Mediator release assay}

For FceRI crosslinking, $2 \times 10^{4}$ MCs were stimulated using the $\mathrm{mAb} 22 \mathrm{E} 7\left(100 \mathrm{ng} / \mathrm{ml}, 30 \mathrm{~min}, 37^{\circ} \mathrm{C}\right)$ directed against the high-affinity FceRI $\alpha$-chain. For IgGcrosslinking, MCs were cultured in RPMI for $24 \mathrm{~h}$ in the presence of $10 \mu \mathrm{g} / \mathrm{ml}$ human plasma IgG (Calbiochem; plasma $\operatorname{IgG}$ were centrifuged before at $20,000 \times \mathrm{g}$ for 
$40 \mathrm{~min}$ at $4^{\circ} \mathrm{C}$ to remove aggregated molecules). Samples were washed twice and $2 \times 10^{4} \mathrm{MCs}$ were resuspended in $400 \mu \mathrm{l}$ HACM buffer ( $20 \mathrm{mM}$ HEPES, $125 \mathrm{mM} \mathrm{NaCl}$, $5 \mathrm{mM}, \mathrm{KCl}, 0.5 \mathrm{mM}, 1 \mathrm{mM} \mathrm{CaCl}, 1 \mathrm{mM} \mathrm{MgCl}_{2}, 0,1 \%$ BSA). Surface bound IgG was crosslinked by an antihuman IgG $\mathrm{mAb}\left(1 \mu \mathrm{g} / \mathrm{ml}, 30 \mathrm{~min}, 37^{\circ} \mathrm{C}\right.$, Becton Dickinson). Histamine (RIA, Coulter-Immunotech, Hamburg, Germany) and leukotriene $\mathrm{C}_{4}$ ( $\mathrm{LTC}_{4}$, ELISA, Biotrend, Cologne, Germany) were measured in the supernatants.

\section{Statistics}

All data in text and figures are expressed as mean \pm SEM. Statistical differences between groups were determined using two-tailed Student's t test.

\section{Abbreviations}

LTC $_{4}$ : Leukotriene $C_{4}$; MC: Mast cell; SCF: Stem cell factor.

\section{Competing interests}

All authors have no competing financial interests.

\section{Authors' contributions}

Conceived and designed the experiments: GS, MB, AL, SCB. Performed the experiments: GS, MB, SK, TG. Analyzed the data: GS, MB. Collected tissues samples and isolated cells: GS, MB, SK, TG, LES. Wrote the paper: GS, LES, AL, SCB. All authors read and approved the final manuscript.

\section{Acknowledgements}

The authors thank Gisela Weier for excellent technical support.

\section{Author details}

${ }^{1}$ Department of Internal Medicine III, University Hospital Aachen, RWTH University, Aachen, Germany. ${ }^{2}$ Department of Obstetrics and Gynecology, Cologne Municipal Health Care, Cologne, Germany. ${ }^{3}$ Department of Nutritional Medicine, University of Hohenheim, Stuttgart, Germany. ${ }^{4}$ Department of Microbiology and Immunology, The University of Melbourne, Melbourne, Australia. ${ }^{5}$ Departmant of Internal Medicine/Infectious Diseases and Respiratory Medicine, Charité - Universitätsmedizin Berlin, Berlin, Germany.

Received: 13 March 2014 Accepted: 20 June 2014 Published: 5 July 2014

\section{References}

1. Bischoff SC: Role of mast cells in allergic and non-allergic immune responses: comparison of human and murine data. Nat Rev/mmunol 2007, 7:93-104

2. Dawicki W, Marshall JS: New and emerging roles for mast cells in host defence. Curr Opin Immunol 2007, 19:31-38.

3. Sayed BA, Christy A, Quirion MR, Brown MA: The master switch: the role of mast cells in autoimmunity and tolerance. Annu Rev Immunol 2008, 26:705-739.

4. Sun J, Sukhova GK, Wolters PJ, Yang M, Kitamoto S, Libby P, MacFarlane LA, Mallen-St Clair J, Shi GP: Mast cells promote atherosclerosis by releasing proinflammatory cytokines. Nat Med 2007, 13:719-724.

5. Gebhardt T, Sellge G, Lorentz A, Raab R, Manns MP, Bischoff SC: Cultured human intestinal mast cells express functional IL-3 receptors and respond to IL-3 by enhancing growth and IgE receptor-dependent mediator release. EurJ Immunol 2002, 32:2308-2316.

6. Ochi H, De Jesus NH, Hsieh FH, Austen KF, Boyce JA: IL-4 and -5 prime human mast cells for different profiles of IgE-dependent cytokine production. Proc Natl Acad Sci USA 2000, 97:10509-10513.

7. Bischoff SC, Sellge G, Lorentz A, Sebald W, Raab R, Manns MP: IL-4 enhances proliferation and mediator release in mature human mast cells. Proc Natl Acad Sci USA 1999, 96:8080-8085.
8. Anthony RM, Rutitzky LI, Urban JF Jr, Stadecker MJ, Gause WC: Protective immune mechanisms in helminth infection. Nat Rev/mmunol 2007, 7:975-987.

9. Schroder K, Hertzog PJ, Ravasi T, Hume DA: Interferon-gamma: an overview of signals, mechanisms and functions. JLeukocBiol 2004, 75:163-189.

10. Nafziger J, Arock M, Guillosson JJ, Wietzerbin J: Specific high-affinity receptors for interferon-gamma on mouse bone marrow-derived mast cells: inhibitory effect of interferon-gamma on mast cell precursors. Eur J Immunol 1990, 20:113-117.

11. Mann-Chandler MN, Kashyap M, Wright HV, Norozian F, Barnstein BO, Gingras S, Parganas E, Ryan JJ: IFN-gamma induces apoptosis in developing mast cells. J Immunol 2005, 175:3000-3005.

12. Deschoolmeester ML, Eastmond NC, Dearman RJ, Kimber I, Basketter DA, Coleman JW: Reciprocal effects of interleukin-4 and interferon-gamma on immunoglobulin E-mediated mast cell degranulation: a role for nitric oxide but not peroxynitrite or cyclic guanosine monophosphate. Immunology 1999, 96:138-144.

13. Coleman JW, Buckley MG, Holliday MR, Morris AG: Interferon-gamma inhibits serotonin release from mouse peritoneal mast cells. Eur J Immunol 1991, 21:2559-2564

14. Okayama Y, Kirshenbaum AS, Metcalfe DD: Expression of a functional high-affinity lgG receptor, Fc gamma Rl, on human mast cells: Up-regulation by IFN-gamma. J Immunol 2000, 164:4332-4339.

15. Kulka M, Metcalfe DD: High-resolution tracking of cell division demonstrates differential effects of $\mathrm{TH} 1$ and $\mathrm{TH} 2$ cytokines on SCFdependent human mast cell production in vitro: correlation with apoptosis and Kit expression. Blood 2005, 105:592-599.

16. Ochi H, Hirani WM, Yuan Q, Friend DS, Austen KF, Boyce JA: T helper cell type 2 cytokine-mediated comitogenic responses and CCR3 expression during differentiation of human mast cells in vitro. JExpMed 1999, 190:267-280.

17. Yanagida M, Fukamachi H, Takei M, Hagiwara T, Uzumaki H, Tokiwa T, Saito $H$, likura $Y$, Nakahata $T$ : Interferon-gamma promotes the survival and Fc epsilon Rl-mediated histamine release in cultured human mast cells. Immunology 1996, 89:547-552.

18. Sillaber C, Sperr WR, Agis H, Spanblochl E, Lechner K, Valent P: Inhibition of stem cell factor dependent formation of human mast cells by interleukin-3 and interleukin-4. Int Arch Allergy Immunol 1994 105:264-268.

19. Thienemann F, Henz BM, Babina M: Regulation of mast cell characteristics by cytokines: divergent effects of interleukin-4 on immature mast cell lines versus mature human skin mast cells. Arch Dermatol Res 2004, 296:134-138.

20. Sellge G, Lorentz A, Gebhardt T, Levi-Schaffer F, Bektas H, Manns MP Schuppan D, Bischoff SC: Human intestinal fibroblasts prevent apoptosis in human intestinal mast cells by a mechanism independent of stem cell factor, IL-3, IL-4, and nerve growth factor. J Immunol 2004, 172:260-267.

21. Gebhardt T, Lorentz A, Detmer F, Trautwein C, Bektas H, Manns MP, Bischoff SC: Growth, phenotype, and function of human intestinal mast cells are tightly regulated by transforming growth factor beta1. Gut 2005, 54:928-934.

22. Lorentz A, Schwengberg S, Sellge G, Manns MP, Bischoff SC: Human intestinal mast cells are capable of producing different cytokine profiles: role of IgE receptor cross-linking and IL-4. J Immunol 2000, 164:43-48.

23. Warbrick EV, Taylor AM, Botchkarev VA, Coleman JW: Rat connective tissue-type mast cells express MHC class II: up-regulation by IFN-gamma. Cell Immunol 1995, 163:222-228.

24. Kambayashi T, Allenspach EJ, Chang JT, Zou T, Shoag JE, Reiner SL, Caton AJ, Koretzky GA: Inducible MHC class II expression by mast cells supports effector and regulatory T cell activation. J Immunol 2009, 182:4686-4695.

25. Love KS, Lakshmanan RR, Butterfield JH, Fox CC: IFN-gamma-stimulated enhancement of MHC class II antigen expression by the human mast cell line HMC-1. Cell Immunol 1996, 170:85-90.

26. Suurmond J, van Heemst J, van Heiningen J, Dorjee AL, Schilham MW, van der Beek FB, Huizinga TW, Schuerwegh AJ, Toes RE: Communication between human mast cells and CD4(+) T cells through antigen-dependent interactions. Eur J Immunol 2013, 43:1758-1768.

27. Kirshenbaum AS, Worobec AS, Davis TA, Goff JP, Semere T, Metcalfe DD: Inhibition of human mast cell growth and differentiation by interferon gamma-1b. ExpHematol 1998, 26:245-251. 
28. Prummer $\mathrm{O}$, Fiehn $\mathrm{C}$, Gallati $\mathrm{H}$ : Anti-interferon-gamma antibodies in a patient undergoing interferon-gamma treatment for systemic mastocytosis. J Interferon Cytokine Res 1996, 16:519-522.

29. Nigrovic PA, Lee DM: Mast cells in inflammatory arthritis. Arthritis ResTher 2005, 7:1-11.

30. Jiang WY, Chattedee AD, Raychaudhuri SP, Raychaudhuri SK, Farber EM: Mast cell density and IL-8 expression in nonlesional and lesional psoriatic skin. IntJDermatol 2001, 40:699-703.

31. Malbec O, Daeron M: The mast cell lgG receptors and their roles in tissue inflammation. ImmunolRev 2007, 217:206-221

32. Kobayashi R, Okamura S, Ohno T, Saito H, Mori M, Ra C, Okayama Y: Hyperexpression of FcgammaRI and Toll-like receptor 4 in the intestinal mast cells of Crohn's disease patients. Clin Immunol 2007, 125:149-158.

33. Zhao W, Kepley CL, Morel PA, Okumoto LM, Fukuoka Y, Schwartz LB: Fc gamma Rlla, not Fc gamma Rllb, is constitutively and functionally expressed on skin-derived human mast cells. JImmunol 2006, 177:694-701.

34. Kepley CL, Taghavi S, Mackay G, Zhu D, Morel PA, Zhang K, Ryan JJ, Satin LS, Zhang M, Pandolfi PP, Saxon A: Co-aggregation of FcgammaRII with FcepsilonRI on human mast cells inhibits antigen-induced secretion and involves SHIP-Grb2-Dok complexes. J Biol Chem 2004, 279:35139-35149.

35. Lee H, Kashiwakura J, Matsuda A, Watanabe Y, Sakamoto-Sasaki T, Matsumoto K, Hashimoto N, Saito S, Ohmori K, Nagaoka M, Tokuhashi Y, Ra C, Okayama: Activation of human synovial mast cells from rheumatoid arthritis or osteoarthritis patients in response to aggregated lgG through Fcgamma receptor I and Fcgamma receptor II. Arthritis Rheum 2013, 65:109-119.

36. Tkaczyk C, Okayama Y, Woolhiser MR, Hagaman DD, Gilfillan AM, Metcalfe DD: Activation of human mast cells through the high affinity lgG receptor. Mol Immunol 2002, 38:1289-1293.

37. Bruhns $P$, lannascoli $B$, England $P$, Mancardi DA, Fernandez N, Jorieux S, Daëron M: Specificity and affinity of human Fcgamma receptors and their polymorphic variants for human IgG subclasses. Blood 2009, 113:3716-3725

38. Okayama Y, Hagaman DD, Metcalfe DD: A comparison of mediators released or generated by IFN-gamma-treated human mast cells following aggregation of Fc gamma RI or Fc epsilon RI. JImmunol 2001, 166:4705-4712.

39. Okayama Y, Hagaman DD, Woolhiser M, Metcalfe DD: Further characterization of FcgammaRII and FcgammaRIII expression by cultured human mast cells. Int Arch Allergy Immunol 2001, 124:155-157.

40. Nimmerjahn F, Ravetch JV: Fcgamma receptors: old friends and new family members. Immunity 2006, 24:19-28.

41. Cady CT, Powell MS, Harbeck RJ, Giclas PC, Murphy JR, Katial RK, Weber RW, Hogarth PM, Johnson S, Bonvini E, Koenig S, Cambier JC: IgG antibodies produced during subcutaneous allergen immunotherapy mediate inhibition of basophil activation via a mechanism involving both FcgammaRIIA and FcgammaRIIB. Immunol Lett 2010, 130:57-65.

42. Daeron M, Latour S, Malbec O, Espinosa E, Pina P, Pasmans S, Fridman WH: The same tyrosine-based inhibition motif, in the intracytoplasmic domain of FC gamma RIIB, regulates negatively BCR-, TCR-, and FcR-dependent cell activation. Immunity 1995, 3:635-646.

43. Kepley CL, Cambier JC, Morel PA, Lujan D, Ortega E, Wilson BS, Oliver JM: Negative regulation of Fc epsilon RI signaling by Fc gamma RII costimulation in human blood basophils. J Allergy Clin Immunol 2000, 106:337-348.

44. Blank MC, Stefanescu RN, Masuda E, Marti F, King PD, Redecha PB, Wurzburger RJ, Peterson MG, Tanaka S, Pricop L: Decreased transcription of the human FCGR2B gene mediated by the $-343 \mathrm{G} / \mathrm{C}$ promoter polymorphism and association with systemic lupus erythematosus. Hum Genet 2005, 117:220-227.

45. Sellge G, Bischoff SC: Isolation, culture, and characterization of intestinal mast cells. Methods Mol Biol 2006, 315:123-138.

doi:10.1186/1471-2172-15-27

Cite this article as: Sellge et al:: Interferon- $\gamma$ regulates growth and controls Fcy receptor expression and activation in human intestinal mast cells. BMC Immunology 2014 15:27.

\section{Submit your next manuscript to BioMed Central and take full advantage of:}

- Convenient online submission

- Thorough peer review

- No space constraints or color figure charges

- Immediate publication on acceptance

- Inclusion in PubMed, CAS, Scopus and Google Scholar

- Research which is freely available for redistribution

Submit your manuscript at www.biomedcentral.com/submit
C) BioMed Central 